\title{
TRPV1-mediated UCP2 upregulation ameliorates hyperglycemia-induced endothelial dysfunction
}

\author{
Jing Sun ${ }^{1 \dagger}$, Yunfei Pu ${ }^{1 \dagger}$, Peijian Wang ${ }^{1}$, Sijiao Chen², Yu Zhao ${ }^{1}$, Chan Liư ${ }^{3}$, Qianhui Shang ${ }^{3}$, Zhiming Zhu ${ }^{1}$ \\ and Daoyan Liu ${ }^{1 *}$
}

\begin{abstract}
Background: Diabetic cardiovascular complications are characterised by oxidative stress-induced endothelial dysfunction. Uncoupling protein 2 (UCP2) is a regulator of mitochondrial reactive oxygen species (ROS) generation and can antagonise oxidative stress, but approaches that enhance the activity of UCP2 to inhibit ROS are scarce. Our previous studies show that activation of transient receptor potential vanilloid 1 (TRPV1) by capsaicin can prevent cardiometabolic disorders. In this study, we conducted experiments in vitro and in vivo to investigate the effect of capsaicin treatment on endothelial UCP2 and oxidative stress. We hypothesised that TRPV1 activation by capsaicin attenuates hyperglycemia-induced endothelial dysfunction through a UCP2-mediated antioxidant effect.

Methods: TRPV1 ${ }^{-1-}, \mathrm{UCP} 2^{-1-}$ and db/db mice, as well as matched wild type (WT) control mice, were included in this study. Some mice were subjected to dietary capsaicin for 14 weeks. Arteries isolated from mice and endothelial cells were cultured. Endothelial function was examined, and immunohistological and molecular analyses were performed.

Results: Under high-glucose conditions, TRPV1 expression and protein kinase A (PKA) phosphorylation were found to be decreased in the cultured endothelial cells, and the effects of high-glucose on these molecules were reversed by the administration of capsaicin. Furthermore, high-glucose exposure increased ROS production and reduced nitric oxide (NO) levels both in endothelial cells and in arteries that were evaluated respectively by dihydroethidium (DHE) and DAF-2 DA fluorescence. Capsaicin administration decreased the production of ROS, restored high-glucose-induced endothelial dysfunction through the activation of TRPV1 and acted in a UCP2-dependent manner in vivo. Administration of dietary capsaicin for 14 weeks increased the levels of PKA phosphorylation and UCP2 expression, ameliorated the vascular oxidative stress and increased NO levels observed in diabetic mice. Prolonged dietary administration of capsaicin promoted endothelium-dependent relaxation in diabetic mice. However, the beneficial effect of capsaicin on vasorelaxation was absent in the aortas of UCP2 ${ }^{-1-}$ mice exposed to high-glucose levels.
\end{abstract}

Conclusion: TRPV1 activation by capsaicin might protect against hyperglycemia-induced endothelial dysfunction through a mechanism involving the PKA/UCP2 pathway.

Keywords: TRPV1, Diabetes, Capsaicin, Endothelium, Oxidative stress, UCP2

\section{Background}

Reactive oxygen species (ROS) generated by hyperglycemia contribute to the development and progression of diabetic vascular complications and are linked to endothelial dysfunction [1-4]. Vascular nicotinamide adenine dinucleotide phosphate $(\mathrm{NAD}(\mathrm{P}) \mathrm{H})$ oxidase activity, mitochondrial

\footnotetext{
* Correspondence: daoyanliu@yahoo.com

${ }^{\dagger}$ Equal contributors

${ }^{1}$ Center for Hypertension and Metabolic Diseases, Department of Hypertension and Endocrinology, Daping Hospital, Third Military Medical University, Chongqing Institute of Hypertension, Chongqing 400042, China Full list of author information is available at the end of the article
}

disturbance and the impairment of endothelial nitric oxide synthase (eNOS) activity all lead to oxidative stress in diabetes $[3,5]$.

Given the importance of oxidative stress in diabetic vascular complications, anti-oxidative stress treatment is a very important intervention that has the potential to ameliorate hyperglycemia-induced vascular lesions. Up to now, several drugs, including statins and angiotensin II receptor blockers, have been reported to offer protection against oxidative stress in diabetic patients with vascular complications $[2,4,6,7]$. Non-pharmaceutical approaches, such as regular 
exercise, also have a beneficial effect in diabetic patients with vascular complications [8], but the underlying mechanisms of this effect are poorly understood.

Uncoupling protein 2 (UCP2) is a member of the mitochondrial anion carrier family that is widely expressed in a variety of tissues [9]. UCP2 is thought to function as a physiological regulator of mitochondrial ROS generation and may contribute to the prevention of diabetes [10,11]. A recent study conducted by our research group showed that UCP2 plays an important role in preventing salt-sensitive hypertension, which is associated with the suppression of superoxide production and the reservation of nitric oxide (NO) bioavailability in blood vessels [12]. Several studies have shown that administration of capsaicin or its analogue can increase UCP2 expression in adipose and hepatic tissues $[13,14]$. Multiple cyclic adenosine monophosphate (cAMP) response elements have been identified in the promoter region of human UCP2, and UCP2 expression is stimulated by the cAMP/PKA signal cascade [15]. Adiponectin has been shown to suppress highglucose-induced ROS production in cultured human umbilical vein endothelial cells through a cAMP/ PKA-dependent pathway [16]. Transient receptor potential vanilloid 1 (TRPV1), a polymodal nonselective cation channel, is expressed in sensory neurons and also present in nonneuronal tissues including blood vessels, is a highly selective stimulated by capsaicin [17]. Our previous studies suggest that activation of TRPV1 is a potential therapeutic target for obesity, hypertension, atherosclerosis and diabetes [18-21]. We also showed that prolonged dietary administration of capsaicin increased NO production remarkably and improved endothelial function through specific targeting of TRPV1-mediated PKA/eNOS phosphorylation [20]. Although it is well documented that oxidative stress contributes to the vascular complications in diabetes, the factors that play a role in protecting against the associated endothelial dysfunction remain to be discovered.

The present study was undertaken to test the hypothesis that TRPV1 activation by capsaicin attenuates hyperglycemia-induced endothelial dysfunction through a UCP2-mediated antioxidant effect. We also elucidated the underlying mechanism by which TRPV1 activation reduces oxidative stress, namely, by modulating the expression of UCP2.

\section{Methods}

\section{Animal treatment}

Matched TRPV1 knockout (TRPV1 ${ }^{-1-}$ ) and C57BL/6J wild type (WT) mice were purchased from Jackson Laboratory (Bar Harbor, ME, USA), as well as matched db/ $\mathrm{db}$ and $\mathrm{C} 57 \mathrm{BL} / \mathrm{KsJ}$ WT mice. Matched UCP2 knockout $\left(\mathrm{UCP}^{-/-}\right)$and $\mathrm{C} 57 \mathrm{BL} / 6 \mathrm{~J}$ WT mice were provided by
Chenyu Zhang (Model Animal Research Center, Nanjing University, Nanjing, China). All mice were housed under a $12 \mathrm{~h} / 12 \mathrm{~h}$ day/night cycle with free access to food and water. In addition, $\mathrm{db} / \mathrm{db}$ and WT mice were fed with normal chow plus $0.01 \%$ capsaicin for 14 weeks. The numbers of mice are 6 in each group. Blood pressure of $d b / d b$ mice measured by the tail-cuff method consciously after 14 weeks period dietary administration. The Institute's Animal Care and Use Committee approved all animal protocols.

\section{Preparation of aortic and mesenteric arteries}

After animals were sacrificed, the thoracic aortas and mesenteric arteries were dissected as previous reported [20], carefully freed from connective tissue, and placed in Krebs solution, containing (in $\mathrm{mmol} / \mathrm{L}$ ) $\mathrm{NaCl} \mathrm{119;}$ $\mathrm{NaHCO}_{3}$ 25; glucose 11.1; $\mathrm{KCl} 4.7 ; \mathrm{KH}_{2} \mathrm{PO}_{4} 1.2 ; \mathrm{MgSO}_{4}$ 1.2; $\mathrm{CaCl}_{2}$ 2.5; $\mathrm{pH} 7.4$.

\section{Measurement of vascular activities}

Changes in the isometric tone of the aortic and mesenteric artery rings were recorded by four-chamber wire myograph (model 610M; Danish Myo Technology, Aarhus, Denmark), as previously described [11,22]. The arterial segments were stretched to an optimal baseline tension and then allowed to equilibrate for one hour before being contracted with $60 \mathrm{mmol} / \mathrm{L} \mathrm{KCl}$ and rinsed in Krebs solution. Endothelium-dependent relaxation was measured by testing the concentration-response relationship upon the cumulative addition of acetylcholine (Ach, $1 \mathrm{nmol} / \mathrm{L}$ to $10 \mu \mathrm{mol} / \mathrm{L}$ ) to phenylephrine (Phe, $1 \mathrm{nmol} / \mathrm{L}$ to $10 \mu \mathrm{mol} /$ $\mathrm{L})$-precontracted rings. In some cases, arteries were incubated with the eNOS inhibitor NG-nitro-L-arginine methyl ester (L-NAME, $100 \mu \mathrm{mol} / \mathrm{L}, 30$ minutes) before Phe-stimulated precontraction. The endotheliumindependent relaxation response to nitroglycerine (NTG) was also measured in artery rings.

\section{Artery and endothelial cell culture}

Mouse aortic rings were dissected in sterile PBS and incubated in DMEM supplemented with $10 \%$ foetal bovine serum (FBS, Gibco), $100 \mathrm{IU} / \mathrm{mL}$ penicillin and $100 \mu \mathrm{g} / \mathrm{mL}$ streptomycin. The high-glucose (HG: $30 \mathrm{mmol} / \mathrm{L}$ ) condition was achieved by the addition of $24.5 \mathrm{mmol} / \mathrm{L}$ glucose, while $24.5 \mathrm{mmol} / \mathrm{L}$ of mannitol was used in the normalglucose (NG) osmotic control condition [1]. After the incubation period, the aortic rings were transferred to a chamber filled with fresh Krebs solution and mounted in a myograph to measure changes in the isometric force [23]. Porcine iliac artery endothelial cells (PIECs) were obtained from the Institute of Biochemistry and Cell Biology [24]. The cells were grown in DMEM supplemented with 10\% FBS and 1\% antibiotics. Cultured arteries and cells were maintained at $37^{\circ} \mathrm{C}$ in a humidified atmosphere 
of $95 \% \mathrm{O}_{2} / 5 \% \mathrm{CO}_{2}$. The cells were made quiescent by incubation of $90 \%$ confluent cell cultures in serum-free DMEM and were incubated with capsaicin $(1 \mu \mathrm{mol} / \mathrm{L})$ for $12 \mathrm{~h}$ in the presence or absence of TRPV1 antagonist 5 '-iodo-resiniferatoxin (iRTX, $1 \mu \mathrm{mol} / \mathrm{L}$ ), PKA inhibitor KT5720 $(2 \mu \mathrm{mol} / \mathrm{L})$ and UCP2 inhibitor genipin $(10 \mu \mathrm{mol} / \mathrm{L})$, concentrations of these chemicals based on our previous reports $[18,20]$.

\section{Dihydroethidium assay}

To assess superoxide production, dihydroethidium (DHE) staining was performed according to a previously described method [25]. Mesenteric arteries were isolated and embedded in tissue-freezing compound. The specimens were cut into $10 \mu \mathrm{m}$ sections and transferred to cover glass before being incubated with DHE diluted in Krebs solution for $45 \mathrm{~min}$ at $37^{\circ} \mathrm{C}$, after which the sections were washed three times in DHE-free Krebs solution. To quantify DHE fluorescence, the glass slides were placed under an inverted fluorescence microscope (Nikon TE2000; Nikon Corporation, Tokyo, Japan) outfitted with a×40 Plan Fluor objective. Images were acquired using NIS-Elements 3.0 software (Nikon), and the fluorescence intensity was analysed.

\section{Evaluation of NO levels}

The NO levels in vessels and PIECs were assessed by staining with DAF-2 DA in Krebs solution for $45 \mathrm{~min}$ at $37^{\circ} \mathrm{C}$ followed by three washes with Krebs solution. Mesenteric arteries were prepared as described above. The NO fluorescence was detected and the fluorescence intensity was analysed as described above.

\section{Immunofluorescence staining}

Aortic segment were fixed with $10 \%$ formalin at room temperature for $60 \mathrm{~min}$ and then bathed in a $2 \%$ hydrogen peroxide methanol solution for $30 \mathrm{~min}$. The vessels were incubated with antibodies against TRPV1 (Alomone Labs, Israel), PKA or UCP2 (Santa Cruz Biotechnology, USA) overnight at $4^{\circ} \mathrm{C}$ and incubated with fluorescent dye-labeled secondary antibodies (ZSGB$\mathrm{BIO}$, China) at room temperature for $30 \mathrm{~min}$. Images were obtained with a TE2000-U Nikon eclipse microscope and analyzed with NIS-Elements imaging software [13].

\section{Western blot analysis}

Immunoblots of TRPV1, PKA, p-PKA, AMPK, UCP2, $\mathrm{p} 22^{\text {phox }}, \mathrm{p}$-eNOS and GAPDH were prepared as previously described [20]. After incubation with secondary antibodies (ZSGB-BIO, China) at room temperature for $2 \mathrm{~h}$, the proteins were detected with enhanced chemiluminescence and quantified using a Gel Doc 2000 Imager (Bio-Rad, USA). Protein expression was normalized to the internal control, GAPDH. All of the primary antibodies were purchased from Santa Cruz Biotechnology (Santa Cruz, CA, USA).

\section{Drugs}

Ach, Phe, L-NAME, NTG, capsaicin, iRTX, KT5720, genipin, DHE and DAF-2 DA were purchased from Sigma-Aldrich, St. Louis, MO, USA.

\section{Statistical analysis}

Data are mean \pm SEM. The maximum response (Emax) were calculated from individual agonist concentrationresponse curves using GraphPad Prism 3.0 (GraphPad Software, San Diego, CA). The statistical differences in mean values were assessed by the Student's $t$-test. Twosided $P$ values $<0.05$ were considered as statistically significant.

\section{Results}

\section{Activation of TRPV1 upregulates UCP2 through PKA} phosphorylation

We first showed that exposure to a high level of glucose (30 mmol/L) decreased TRPV1 expression and PKA phosphorylation in cultured endothelial cells compared with control cells and that these effects can be reversed by the administration of capsaicin $(1 \mu \mathrm{mol} / \mathrm{L})$. In contrast, the effects of capsaicin were blocked by the addition of the specific TRPV1 antagonist iRTX $(1 \mu \mathrm{mol} / \mathrm{L})$ and the PKA inhibitor KT5270 (2 $\mu \mathrm{mol} / \mathrm{L})$ (Figure $1 \mathrm{~A}$ and B). In addition, high-glucose conditions increased the endothelial UCP2 level. Administration of capsaicin further increased the level of UCP2 in the cultured endothelial cells incubated in high-glucose conditions, but again, this effect of capsaicin was inhibited by antagonists of TRPV1 and inhibitor of PKA and by the UCP2 inhibitor, genipin $(10 \mu \mathrm{mol} / \mathrm{L})$ (Figure 1C). Genipin significantly reduced UCP2, but iRTX and KT5720 did not affect UCP2 levels in normal-glucose solution (Additional file 1: Figure S1). These results indicated that the upregulation of UCP2 occurred through a TRPV1 activation-mediated PKA pathway.

\section{Effect of TRPV1 activation on the production of ROS and NO through the PKA/UCP2 pathway}

$\mathrm{NAD}(\mathrm{P}) \mathrm{H}$ oxidase has been implicated as the major source of ROS generation and plays a role in eNOS uncoupling in the vasculature in response to high-glucose conditions [26]. UCP2 is a physiological regulator of mitochondrial ROS generation. We showed that high-glucose exposure significantly increased the $\mathrm{p} 22^{\text {phox }}$ subunit of NAD (P)H oxidase, but this effect was blunted by capsaicin treatment in the cultured endothelial cells. Furthermore, the inhibition of TRPV1, PKA and UCP2 using their respective antagonists abolished the effects of capsaicin (Figure 2A and B). Also, these effects were observed in endothelial cells 

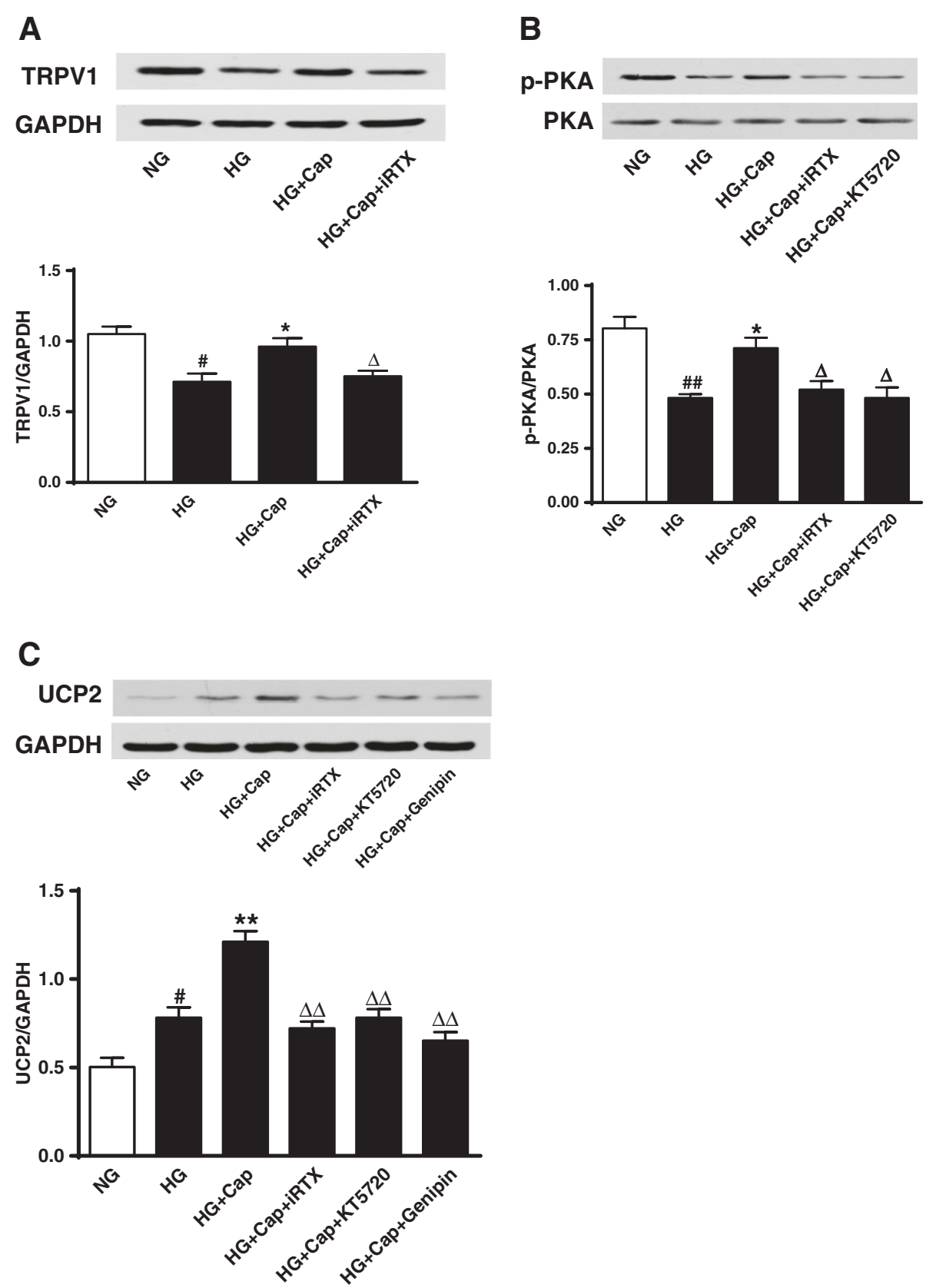

Figure 1 Activation of TRPV1 up-regulates UCP2 through PKA phosphorylation. A, B and C: Representative western blot images showing protein expressions of TRPV1 (A), p-PKA/PKA (B) and UCP2 (C) in endothelial cells cultured with normal-glucose (NG, glucose 5.5 mmol/L), high-glucose (HG,

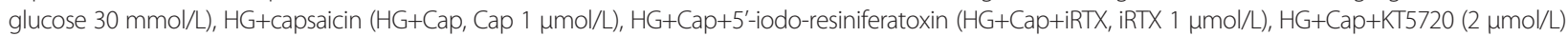

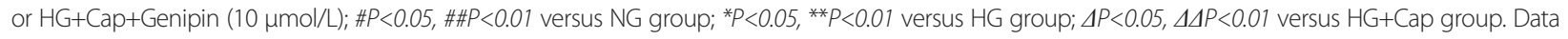
are mean \pm SEM. Each $n=3$.

on normal-glucose condition (Additional file 1: Figure S2A). In addition, high-glucose conditions increased the production of ROS, which was assessed using dihydroethidium (DHE) fluorescence, and reduced the level of NO, which was evaluated by DAF-2 DA fluorescence. However, capsaicin treatment decreased the production of ROS and increased NO levels in the cultured endothelial cells that were exposed to high-glucose conditions, and these effects were antagonised by the inhibition of TRPV1, PKA and UCP2 (Figure 2C-F). Moreover, iRTX, KT5720 or genipin increased ROS level and decreased NO production of endothelial cells on high-glucose condition separately (Additional file 1: Figure S2B). These results suggest that TRPV1 activation by capsaicin reduces the level of 
(See figure on previous page.)

Figure 2 The effect of TRPV1 activation on the production of ROS and NO through the PKA/UCP2 pathway. A and B: Representative western blot images (A) and summary data (B) showing P22 $2^{\text {phox }}$ protein level in endothelial cells cultured with normal-glucose (NG, glucose 5.5

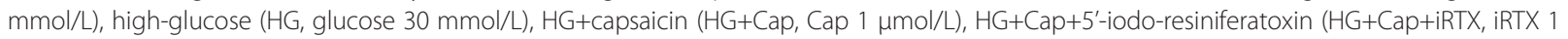
$\mu \mathrm{mol} / \mathrm{L}), \mathrm{HG}+\mathrm{Cap}+\mathrm{KT} 5720(2 \mu \mathrm{mol} / \mathrm{L}), \mathrm{HG}+\mathrm{Cap}+\mathrm{Genipin}(10 \mu \mathrm{mol} / \mathrm{L})$. \#\#P <0.01 versus NG group; ${ }^{* *} P<0.01$ versus HG group; $\triangle \Delta P<0.01$ versus HG+Cap group; Data are mean \pm SEM. Each $n=3$. C-F: Representative endothelial cells stained by DHE $(\mathbf{C}$ and $\mathbf{E})$ and DAF-2 DA (D and F) cultured with NG, HG, HG+Cap, HG+Cap+iRTX, HG+Cap+KT5720, HG+Cap+Genipin. \#\#P<0.01 versus NG group; **P $<0.01$ versus HG group; $\triangle \Delta P<0.01$ versus $\mathrm{HG}+\mathrm{Cap}$ group. Data are mean \pm SEM from 4 independent experiments. The scale bar indicates $50 \mu \mathrm{m}$.

ROS and increases NO production via the PKA/UCP2 pathway.

\section{TRPV1 activation ameliorates high-glucose-induced endothelial dysfunction in a UCP2-dependent manner}

To further determine the role of UCP2, we investigated the vasodilatation effect of capsaicin on aortic artery rings ex vivo under high-glucose conditions. Immunofluorescence images clearly showed the distribution of TRPV1, PKA and UCP2 in the vascular endothelium (Figure 3A). High-glucose (HG) exposure for $12 \mathrm{~h}$ impaired the endothelium-dependent relaxation of aortic rings from both WT and TRPV1 ${ }^{-1-}$ mice as compared with the normal-glucose (NG) exposure condition. Under HG conditions, incubation in the presence of capsaicin for $12 \mathrm{~h}$ improved the endothelium-dependent relaxation of aortic rings from WT mice but not that of aortic rings from $\mathrm{TRPV}^{-1-}$ mice (Figure $3 \mathrm{~B}$ and $\mathrm{C}$ ). We next used the $\mathrm{UCP}^{-/-}$mice and their matched WT counterparts to explore the role of UCP2 in TRPV1 activation-mediated effects. Incubation with capsaicin did not improve the endothelium-dependent relaxation of aortas from $\mathrm{UCP}^{-/-}$mice under high-glucose conditions (Figure 3F). The endothelium-independent relaxations did not differ among the groups tested (Figure 3D, E and G). Exposure to high-glucose condition decreased TRPV1 expression and phosphorylation of PKA, but increased the UCP2 level in cultured aortas compared with control aortas in normal-glucose, these effects can be reversed by capsaicin administration. However, capsaicin administration further elevated the level of UCP2 in the cultured endothelial aortas under highglucose condition (Additional file 1: Figure S3A). Acetylcholine induced endothelial-dependent vasodilation of $\mathrm{UCP}^{-/-}$mice was weakened by pre-cultured with highglucose for $12 \mathrm{~h}$ (Additional file 1: Figure S3B). These results indicate that TRPV1 activation ameliorates high-glucose-induced endothelial dysfunction in a UCP2-dependent manner.

TRPV1 activation by dietary capsaicin promotes endothelial PKA phosphorylation and increases UCP2 levels in diabetic mice

We investigated whether dietary capsaicin has a beneficial effect on UCP2 level in the vasculature. Diabetic obese mice $(\mathrm{db} / \mathrm{db})$ and wild-type lean littermate control mice (C57BL/KsJ) were examined. TRPV1 and phosphorylation of PKA, but not total PKA were significantly down-regulation in the aorta and mesenteric arteries from $\mathrm{db} / \mathrm{db}$ mice compared to lean wild type mice, but increased after dietary capsaicin administration for 14 weeks (Figure 4A-D). We found that UCP2 level was significantly higher and administration of dietary capsaicin was further elevated in the aorta from $\mathrm{db} / \mathrm{db}$ mice compared to lean wild type mice (Figure 4E). These results indicate that TRPV1 activation by dietary capsaicin promotes endothelial PKA phosphorylation and increases the expression level of UCP2 in diabetic mice.

\section{TRPV1 activation by dietary capsaicin attenuates endothelial oxidative stress and increases NO levels in diabetic mice}

We next investigated the effects of PKA phosphorylation and UCP2 upregulation on oxidative stress and endothelial NO production in mesenteric arteries. Immunoblotting showed that dietary capsaicin decreased the vascular expression of $\mathrm{p} 22^{\text {phox }}$ and increased the level of p-eNOS in the aorta in $\mathrm{db} / \mathrm{db}$ mice (Figure $5 \mathrm{~A}$ and $\mathrm{B}$ ). Additionally, chronic dietary capsaicin significantly reduced superoxide anion production and increased $\mathrm{NO}$ production in the mesenteric arteries in $\mathrm{db} / \mathrm{db}$ mice and wild type mice (Figure 5C-D). These results indicate that long-term administration of dietary capsaicin ameliorates vascular oxidative stress and increases NO levels in diabetic mice.

\section{Dietary capsaicin improves endothelium-dependent relaxation in $\mathrm{db} / \mathrm{db}$ mice}

Dietary capsaicin did not affect the blood pressure (data not shown) but markedly augmented the endotheliumdependent relaxation observed in both the aorta and mesenteric arteries (MA) of $\mathrm{db} / \mathrm{db}$ mice (Aorta Emax (\%): $45.59 \pm 2.35$ in control vs $71.07 \pm 3.02$ in capsaicinadministered mice, $P<0.01$; MA $\operatorname{Emax}(\%): 50.36 \pm 3.73$ in control vs $62.94 \pm 2.68$ in capsaicin-administered mice, $P<0.05$ ) (Figure $6 \mathrm{~A}$ and $\mathrm{C}$ ). This difference was abolished by pretreatment with L-NAME (Aorta Emax (\%): $24.02 \pm 2.43$ in control vs27.25 \pm 2.36 in capsaicinadministered mice, $P>0.05$; MA $\operatorname{Emax}(\%): 37.56 \pm 3.41$ in control vs $45.01 \pm 5.61$ in capsaicin-administered mice, $P>0.05$ ) (Figure 6B and D). Endothelium-independent 


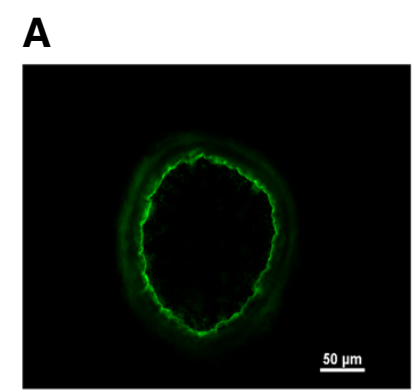

TRPV1

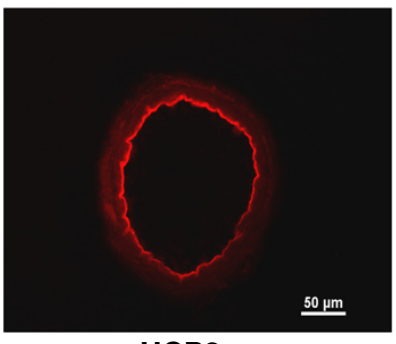

UCP2

B

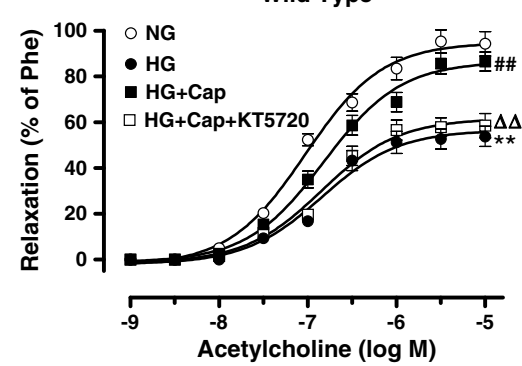

D

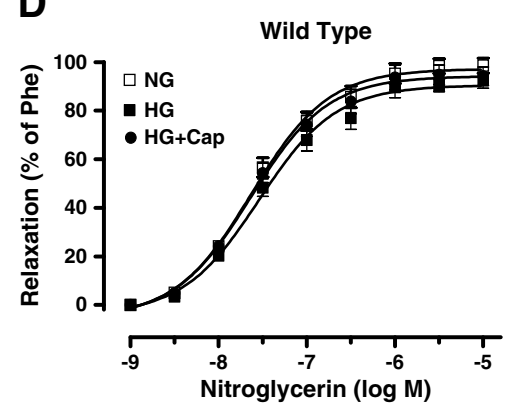

$\mathbf{F}$

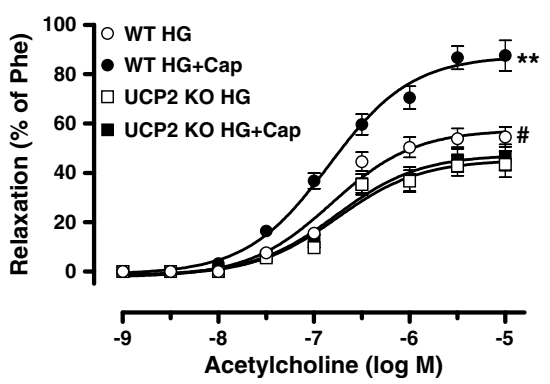

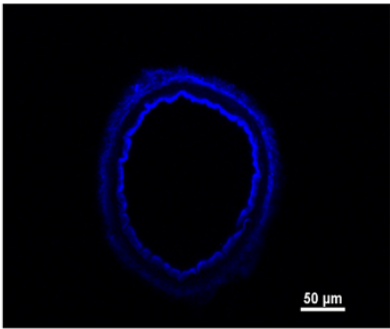

PKA

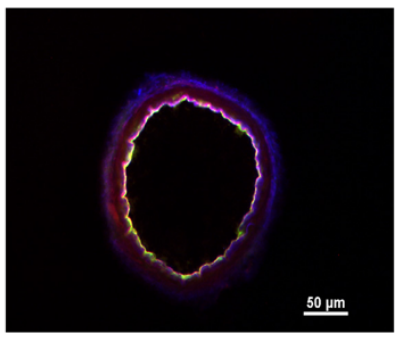

MERGED

C

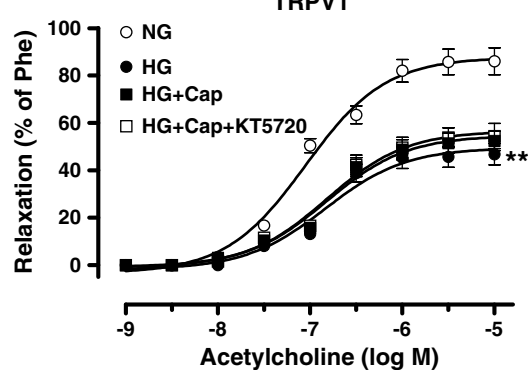

E

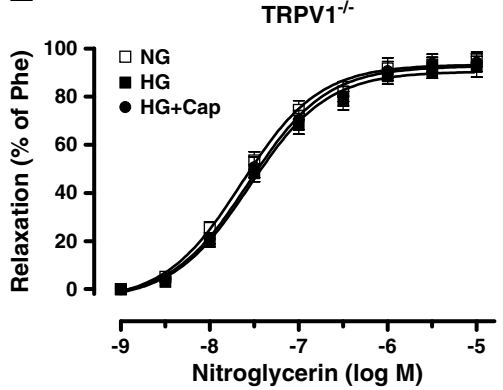

G

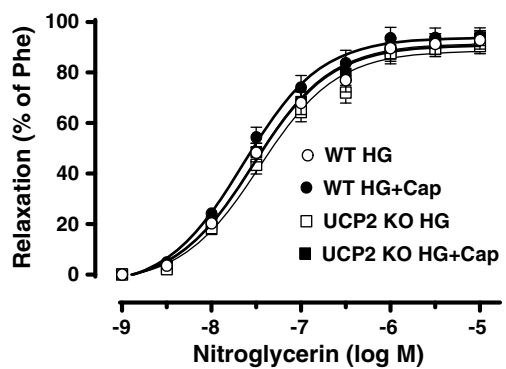

Figure $\mathbf{3}$ (See legend on next page.) 
(See figure on previous page.)

Figure 3 TRPV1 activation ameliorates high-glucose-induced endothelial dysfunction in a UCP2-dependent manner. A: Representative immunofluorescence images showing the co-expression of TRPV1, PKA and UCP2 in the aortas from wild type mice, particularly in the endothelium (Bar denotes $50 \mu \mathrm{m}$ ). B and C: Acetylcholine (1 nmol/L to $10 \mu \mathrm{mol} / \mathrm{L}$ )-induced endothelium-dependent relaxation of isolated aortic artery rings from wild type and TRPV1 ${ }^{-1-}$ mice, pre-incubated with normal-glucose for 12 hours (NG, glucose 5.5 mmol/L), high-glucose (HG, glucose $30 \mathrm{mmol} / \mathrm{L}), \mathrm{HG}+$ capsaicin (HG+Cap, Cap $1 \mu \mathrm{mol} / \mathrm{L}), \mathrm{HG}+\mathrm{Cap}+\mathrm{KT} 5720(2 \mu \mathrm{mol} / \mathrm{L}) ;{ }^{* *} P<0.01$ versus NG group; \#\#P<0.01 versus HG group; $\triangle \triangle P<0.01$ versus HG+Cap group. Data are mean \pm SEM. Each $n=6$. $\mathbf{D}$ and $\mathbf{E}$ : Nitroglycerin $(1 \mathrm{nmol} / \mathrm{L}$ to $10 \mu \mathrm{mol} / \mathrm{L})$-induced endotheliumindependent relaxation of isolated aortic artery rings from wild type and TRPV $1^{-1-}$ mice, after cultured for 12 hours with NG, HG, HG+Cap. Data are mean \pm SEM. Each $n=6$. F and $\mathbf{G}$ : Representative data that Acetylcholine- and nitroglycerin-induced relaxation in the presence or absence of capsaicin (Cap, $1 \mu \mathrm{mol} / \mathrm{L})$ in isolated aortic arteries rings from UCP2 ${ }^{-1-}$ mice and wild type (WT) mice under high-glucose condition(HG). ${ }^{* *} P<0.01$ HG + Cap versus HG group of WT, $\# P<0.05$ HG group of WT versus HG group of UCP2 $2^{-1-}$. Data are mean \pm SEM. Each $n=6$.

relaxation induced by nitroglycerine did not differ among the groups tested (Figure $6 \mathrm{E}$ and $\mathrm{F}$ ). These findings indicate that prolonged administration of dietary capsaicin promotes endothelium-dependent relaxation in diabetic mice.

\section{Discussion}

The major findings from this study are described here. First, upregulation of UCP2 by capsaicin reduced the production of ROS and increased the levels of $\mathrm{NO}$ in cultured endothelial cells through a TRPV1 activation-mediated PKA pathway. Second, TRPV1 activation by capsaicin ameliorated high-glucose-induced endothelial dysfunction in a UCP2-dependent manner. Third, prolonged administration of dietary capsaicin increased the vascular levels of PKA phosphorylation and of UCP2 expression, ameliorated vascular oxidative stress and improved endotheliumdependent relaxation in diabetic mice.

TRPV1 plays a role in promoting insulin secretion in beta cells $[27,28]$ and the stimulation of insulin receptors in the vasculature affects endothelial function [29-31]. Our previous study showed that TRPV1 activationstimulated GLP-1 secretion could be a promising approach for the intervention of diabetes [19]. Furthermore, current study also shows that activation TRPV1 by capsaicin can increase UCP2 expression [13,14]. Oktavianthi, et al demonstrated the importance of common UCP2 gene polymorphisms in the development of obesity in a Balinese population [32]. Treatment with $6 \mathrm{mg} / \mathrm{d}$ capsinoids orally was associated with abdominal fat loss [33]. Capsaicin is a specific agonist of TRPV1 channels and dose dependently induced calcium influx in endothelial cells and in freshly isolated mesenteric arteries $[17,20]$. Several studies show that hyperglycemia cause a dysfunction and down-regulation of TRPV1 in diabetic animals [34-36]. In addition, highglucose reduced phosphorylation of PKA [37] and increased UCP2 level in pancreatic islets of animal models of type 2 diabetes [38]. Our results from $\mathrm{db} / \mathrm{db}$ mice are agreement with these studies.

The underlying mechanisms of cardiovascular complications in diabetic patients are incompletely understood
[2]. However, hyperglycemia plays a pivotal role in endothelial cell dysfunction, and induce mitochondrial ROS generation contribute to diabetic vascular lesions [2,4]. The increased activation of proinflammatory factors is related to hyperglycemic damage, which is mainly caused by a hyperglycemia-induced overproduction of superoxide anion through mitochondrial electron transport chain [39]. Dhamrait.S, et al, showed that UCP2 expression is induced by oxidative stress, which protecting against further ROS generation. Increased UCP2 activity may therefore limit ROS generation, decreasing atherosclerotic risk in diabetic man [40]. Thus, an elevated UCP2 in response to an elevation in superoxide under high-glucose condition plays an active role in feedback regulation of ROS production associated with oxidative stress [41] Antagonising ROS by treatment with antioxidants such as tempol promotes endothelium-dependent vasodilatation in hypertensive and diabetic animal models $[42,43]$. Several studies have shown that UCP2 deficiency causes vascular dysfunction and target organ damage in stroke, atherosclerosis and hypertension $[7,12,42]$. NADPH oxidases are major sources of ROS in the vasculature. NADPH oxidase consists of six subunits: two trans-membrane units, $\mathrm{p} 22^{\text {phox }}$ and gp91 ${ }^{\text {phox }}$, and four cytosolic units, $\mathrm{p} 47^{\text {phox }}, \mathrm{p} 67^{\text {phox }}, \mathrm{p} 40^{\text {phox }}$ and the small GTPase rac1 or rac2.High-glucose levels stimulate ROS production through the activation of NADPH oxidase $[2,4,44]$. The expression of $\mathrm{p} 22^{\text {phox }}$ is significantly increased in rat and human diabetic arteries [4]. Overexpression of UCP2 can protect the vasculature against the effects of high-glucose exposure by inhibiting NADPH oxidase activity [8].

The present study demonstrates that the administration of capsaicin can significantly increase the vascular expression level of UCP2, both in the presence of high-glucose levels and in diabetic mice. Furthermore, high-glucose- or hyperglycemia-induced ROS production and endothelial dysfunction can be blunted by the administration of capsaicin. We further investigated the mechanism responsible for the protective role of capsaicin observed in this study. It has been shown that several protein kinases, such as adenosine monophosphate activated protein kinase (AMPK) 
A
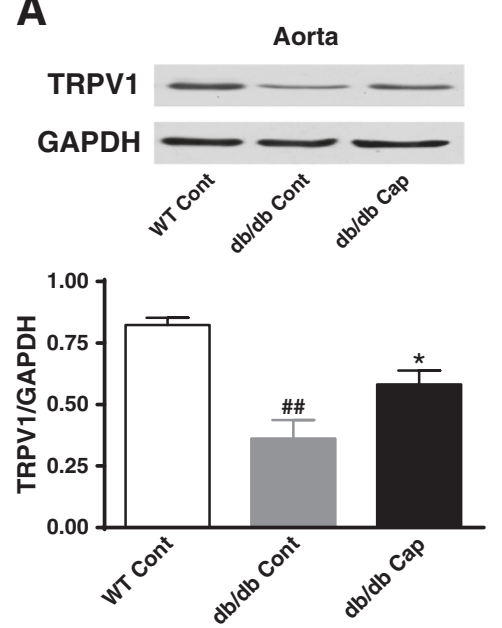

C
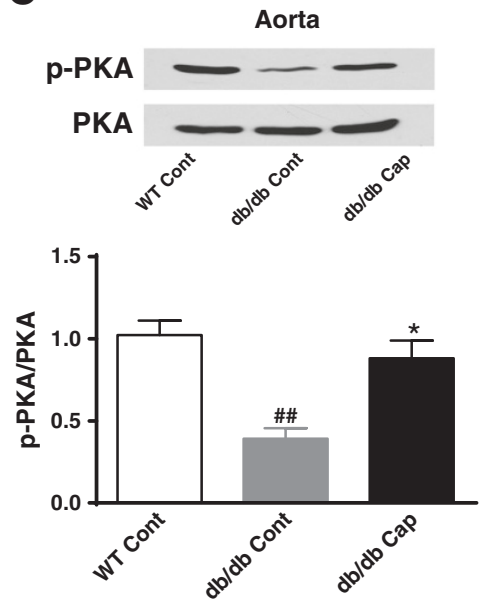

$\mathbf{E}$
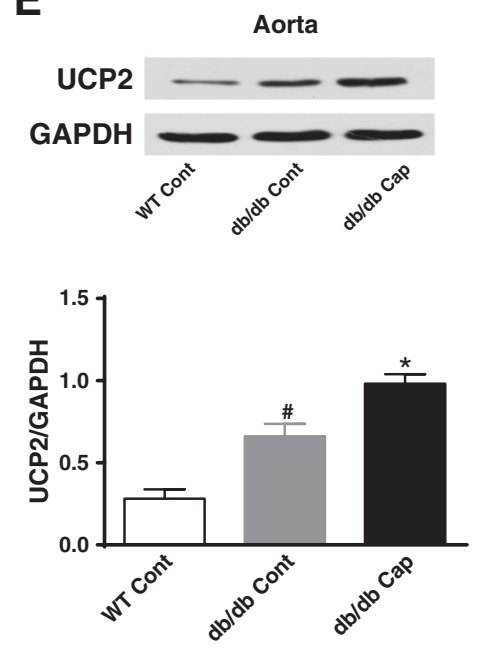

E
B
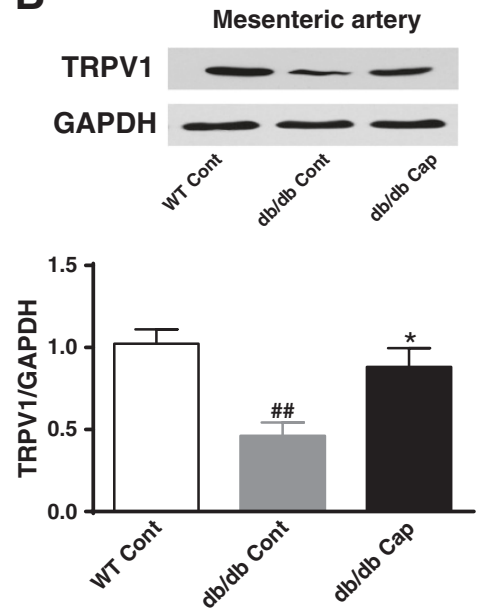

D
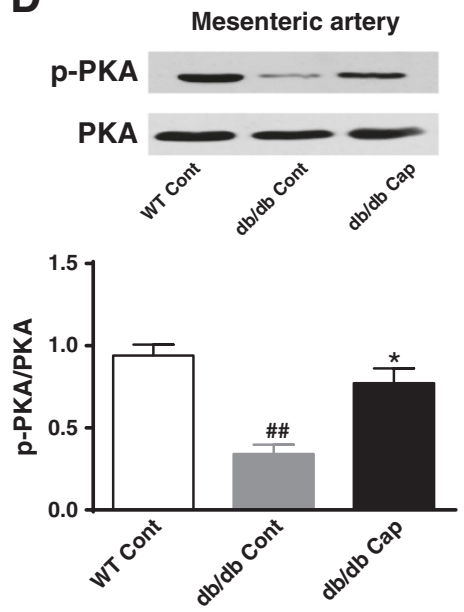

Figure 4 TRPV1 activation by dietary capsaicin promotes endothelial PKA phosphorylation and increases UCP2 levels in diabetic mice. Representative protein expression of TRPV1 (A and B), p-PKA/PKA (C and D) and UCP2 (E) levels in aorta or mesenteric arteries from db/db mice treated with normal diet (db/db Cont) or normal diet plus $0.01 \%$ capsaicin (db/db Cap) and the lean littermate control C57BL/KsJ mice treated with normal diet (WT Cont). Data are mean \pm SEM. Each $n=3$. \#\#P<0.01, \#P<0.05 versus WT Cont group; ${ }^{*} P<0.05$ versus db/db Cont group. 
B

A
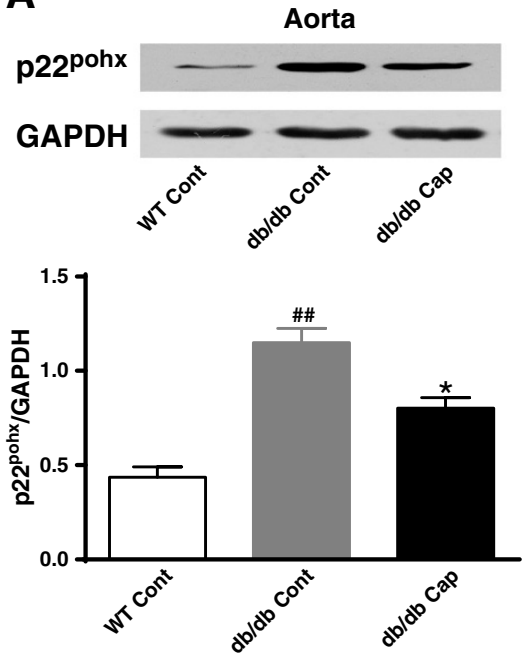

C
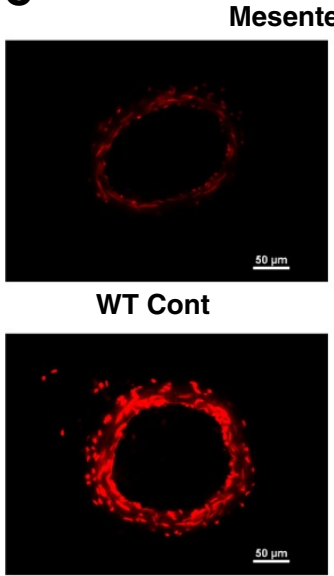

$\mathrm{db} / \mathrm{db}$ Cont

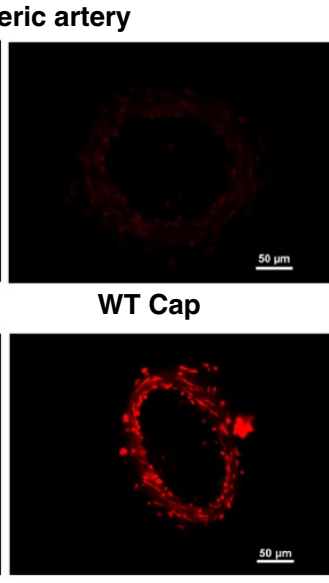

$\mathrm{db} / \mathrm{db}$ Cap

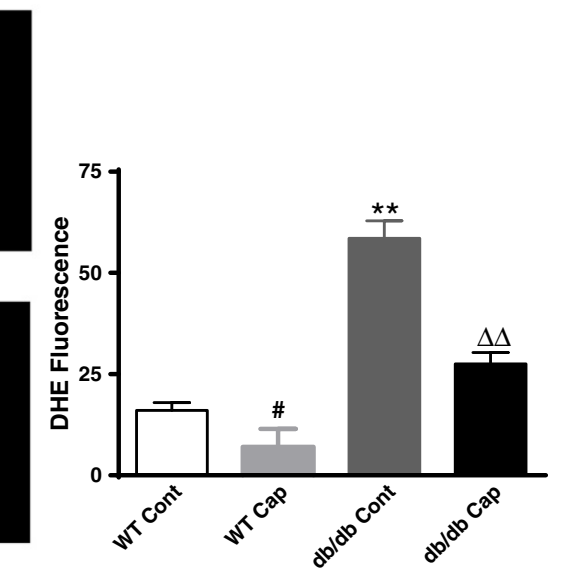

D

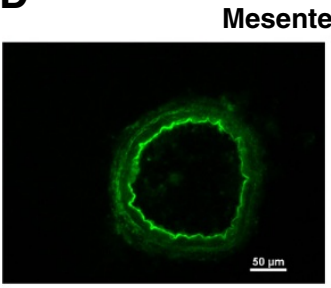

WT Cont

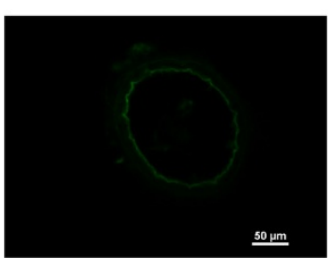

$\mathrm{db} / \mathrm{db}$ Cont
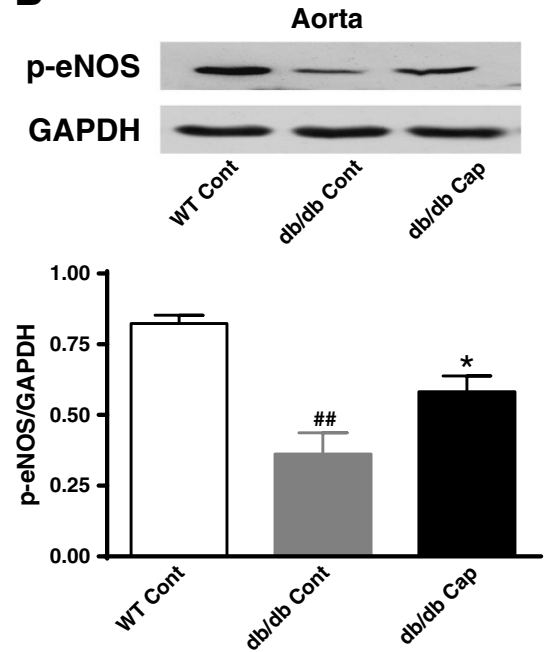

eric artery
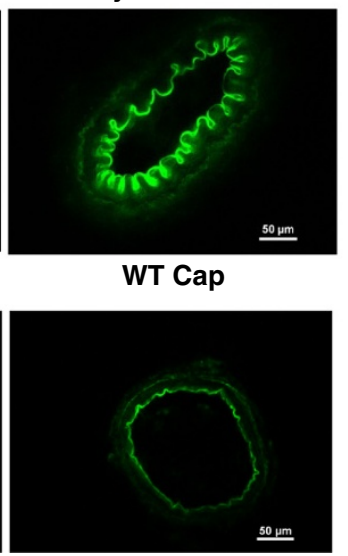

$\mathrm{db} / \mathrm{db}$ Cap

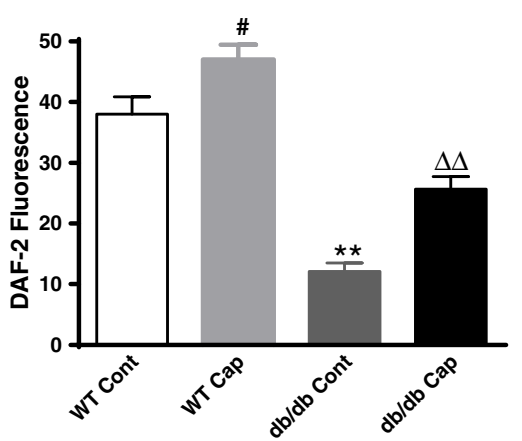

Figure $\mathbf{5}$ (See legend on next page.) 
(See figure on previous page.)

Figure 5 TRPV1 activation by dietary capsaicin attenuates endothelial oxidative stress and increases the level of NO in diabetic mice. $\mathbf{A}$ and $\mathbf{B}$ : Representative protein expressions of $\mathrm{p}_{2} 2^{\text {phox }}(\mathbf{A})$ and $\mathrm{p}$-eNOS (B) in aortas from $\mathrm{db} / \mathrm{db}$ mice treated with normal diet (db/db Cont) or normal diet plus $0.01 \%$ capsaicin (db/db Cap) and wild type mice treated with normal diet (WT Cont). \#\#P<0.01 versus the WT Cont group; ${ }^{*} P<0.05$ versus the $\mathrm{db} / \mathrm{db}$ Cont group. Data are mean \pm SEM. Each $\mathrm{n}=3$. C and $\mathbf{D}$ : Representative images and summary data detected by $\mathrm{DHE}$ (C) and DAF-2 DA (D) in mesenteric arteries from wild type and db/db mice treated with normal diet (WT Cont and db/db Cont) or normal diet plus $0.01 \%$ capsaicin (WT Cap and db/db Cap). \#P<0.05 versus WT Cont group; ${ }^{* *} \mathrm{P}<0.01$ versus WT Cap group; $\Delta \Delta \mathrm{P}<0.01$ versus db/db cont group. Data are mean \pm SEM. Each $n=4$. The scale bar indicates $50 \mu \mathrm{m}$.
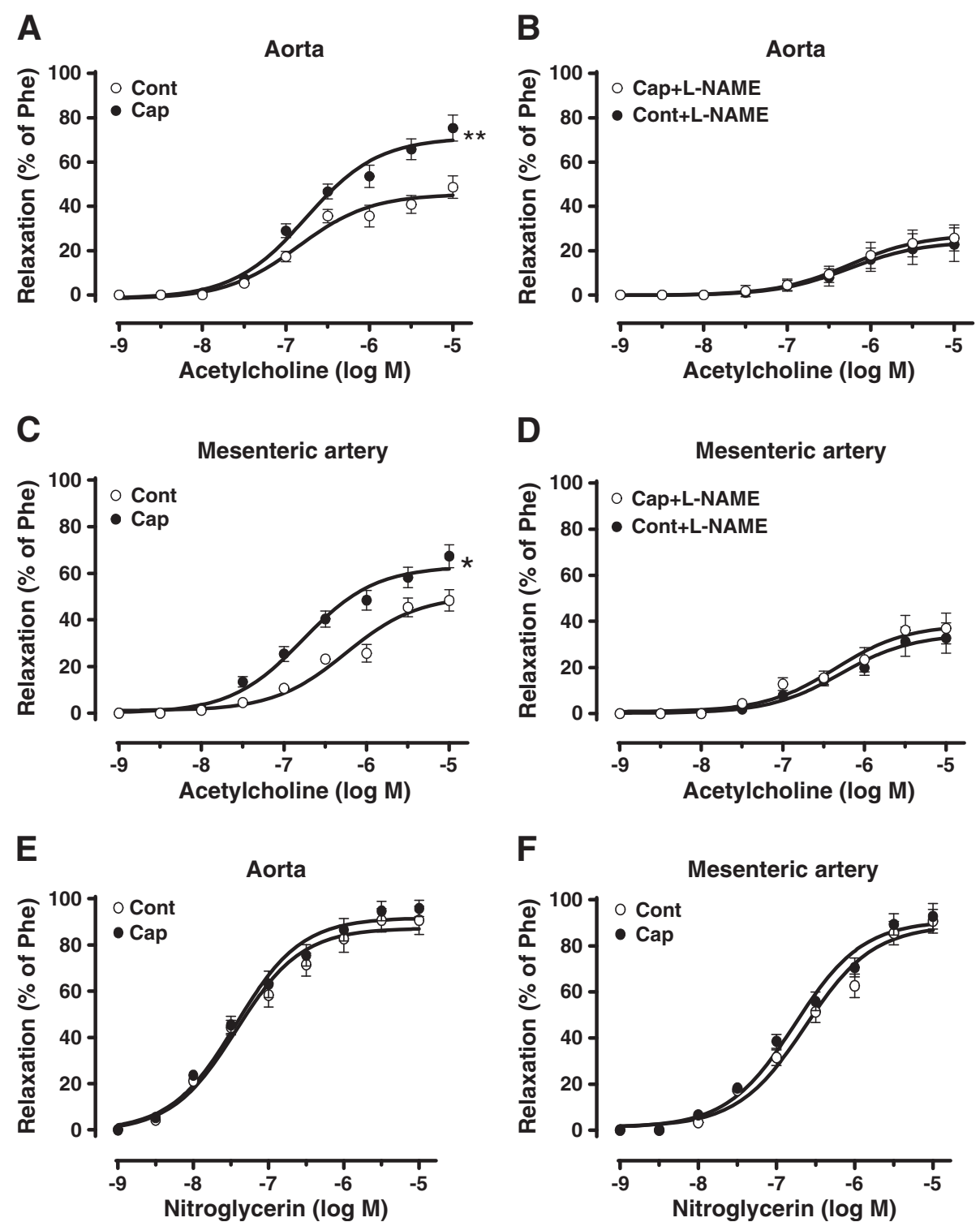

Figure 6 Dietary capsaicin improves the endothelium-dependent relaxation in $\mathbf{d b} / \mathbf{d b}$ mice. A and C: Quantification of the endotheliumdependent relaxation induced by acetylcholine treatment ( $1 \mathrm{nmol} / \mathrm{L}$ to $10 \mu \mathrm{mol} / \mathrm{L}$ ) of aortas and mesenteric arteries from $\mathrm{db} / \mathrm{db}$ mice given either a normal diet (Cont) or a normal diet plus $0.01 \%$ capsaicin (Cap) for 14 weeks. Data are expressed as the mean \pm SEM from six rings, with six mice per group. ${ }^{*} \mathrm{P}<0.05$, ${ }^{*} \mathrm{P}<0.01$ versus the $\mathrm{db} / \mathrm{db}$ control group. $\mathbf{B}$ and $\mathbf{D}$ : The inhibitory effect of nitro-L-arginine methyl ester (L-NAME, $100 \mu \mathrm{M}, 30 \mathrm{~min}$ ), on acetylcholine-induced maximal relaxation in aortas and mesenteric arteries from $\mathrm{db} / \mathrm{db}$ mice with or without dietary capsaicin administration. Data are expressed as the mean \pm SEM from six rings, with six mice per group. $\mathbf{E}$ and $\mathbf{F}$ : Representative data showing endothelium-independent relaxation in $\mathrm{db} / \mathrm{db}$ mouse aortas and mesenteric arteries with or without dietary capsaicin administration. Data are expressed as the mean \pm SEM from six rings, with six mice per group. 


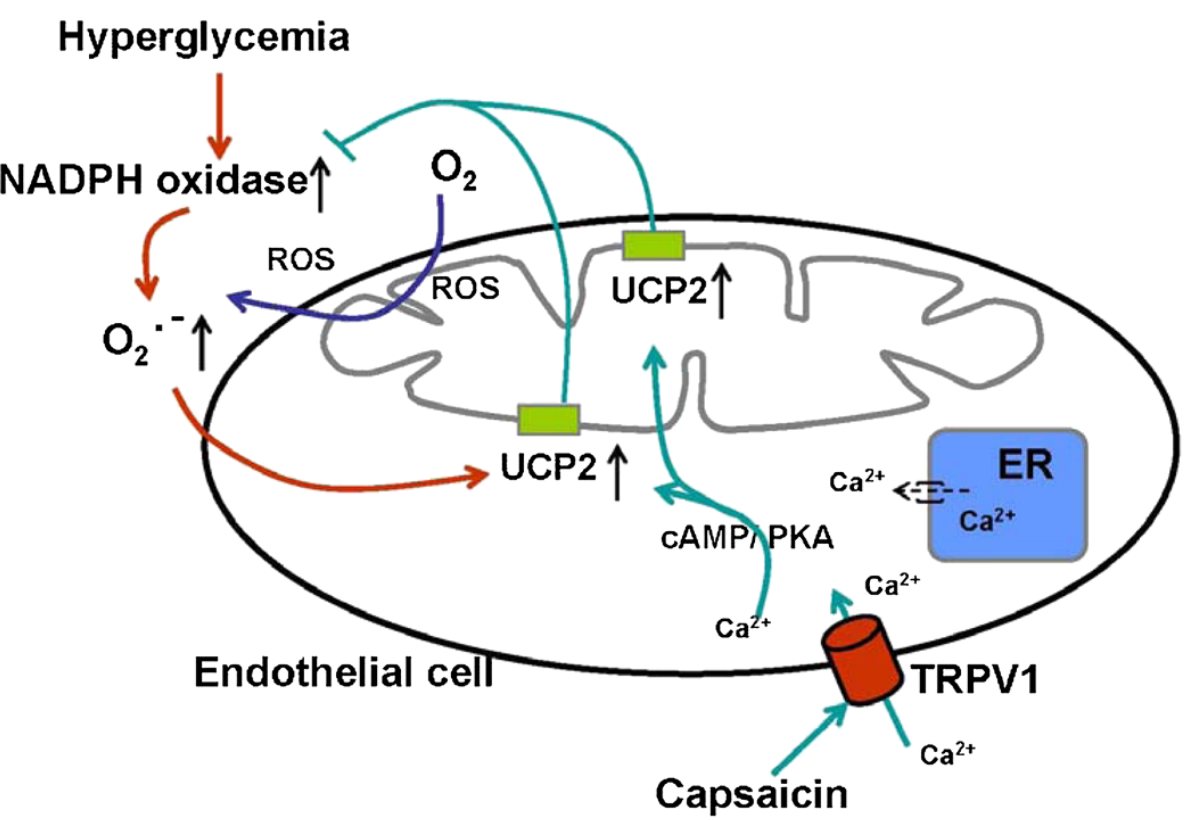

Figure 7 Upregulation of UCP2 by TRPV1 activation attenuates hyperglycemia-induced ROS production in ECs. The increased metabolism of glucose due to intracellular hyperglycemia leads to the overproduction of $\mathrm{NADH}$, a critical component of the superoxidegenerating mechanism in endothelial cells. Upregulation of mitochondrial UCP2 in response to elevated superoxide levels plays an active role in the feedback regulation of reactive oxygen species production that is associated with chronic oxidative stress. Activation of the endothelial TRPV1 channel in endothelial cells by dietary capsaicin mediates the phosphorylation of PKA and upregulates UCP2, thus inhibiting the activity of $\mathrm{NADPH}$ and decreasing ROS production in ECS.

and PKA, modulate UCP2 expression and decrease ROS production $[8,27,45]$. Furthermore, adiponectin reverses hyperglycemia-associated endothelial ROS generation via a cAMP/PKA pathway [16]. Our previous studies showed that dietary capsaicin improved endothelium-dependent vasorelaxation in a hypertensive rat genetic model and ameliorated atherosclerosis in apolipoprotein E deficient $\left(\mathrm{ApoE}^{-/-}\right)$mice through the promotion of PKA phosphorylation [18]. The present study examined the coexpression of TRPV1, PKA and UCP2 in the vasculature. Administration of capsaicin resulted in a remarkable upregulation of UCP2 expression through a TRPV1-mediated PKA pathway. Furthermore, the high-glucose-induced impairment of vasorelaxation observed in aortic rings from UCP2 knockout mice was not ameliorated by capsaicin administration. Our study indicates that capsaicin treatment prevents high-glucose-induced endothelial cell dysfunction through TRPV1/PKA pathway-mediated upregulation of UCP2, which ultimately leads to a reduction in oxidative stress and protects endothelial cells from damage.

\section{Limitations}

There are several limitations in this study. Long-term consumption of capsaicin may affect brain or stomach. The effects of capsaicin on these organs need to be clarified in future. It is worthy to further validate the benefit effect of dietary capsaicin on endothelial function in diabetic patients.

\section{Conclusion}

In summary, this study shows that the administration of capsaicin can reverse high-glucose-induced endothelial dysfunction through TRPV1 activation. Our mechanistic evidence suggests that this vascular benefit is likely to result from an enhancement of the phosphorylation of PKA and from the upregulation of UCP2 expression, which thus reduces oxidative stress and increases the level of NO. This effect accounts for the endothelium-dependent relaxation observed in capsaicin-treated $\mathrm{db} / \mathrm{db}$ mice (Figure 7). Our findings provide new insight into activation of TRPV1 by dietary capsaicin may represent a promising lifestyle intervention and beneficial to the vascular complications in diabetic patients.

\section{Additional file}

Additional file 1: Figure S1. Effect of iRTX, KT5720 and genipin on UCP2 of endothelial cells on normal-glucose condition. Figure S2: A. Effect of capsaicin on p22 $2^{\text {phox }}$ of endothelial cells on normal-glucose condition. B. Effect of iRTX, KT5720 and genipin on ROS level and NO 
production of endothelial cells on high-glucose condition. Figure S3: A. Effect of capsaicin on TRPV1, p-PKA/PKA and UCP2 in aortas of rats on high-glucose condition. B. Endothelial-dependent vasodilation of UCP2 $\mathrm{KO}$ mice in normal or high-glucose solution.

\section{Abbreviations}

UCP2: Uncoupling protein 2; ROS: Reactive oxygen species; TRPV1: Transient receptor potential vanilloid 1; WT: Wild type; PKA: Protein kinase A; NO: Nitric oxide; DHE: Dihydroethidium; NAD(P)H: Nicotinamide adenine dinucleotide phosphate; eNOS: Endothelial nitric oxide synthase; CAMP: Cyclic adenosine monophosphate; NTG: Nitroglycerine; NG: Normal-glucose; HG: High-glucose; L-NAME: NG-nitro-L-arginine methyl ester; PIECs: Porcine iliac artery endothelial cells; iRTX: 5'-iodo-resiniferatoxin: M, mol/L.

\section{Competing interests}

The authors declare that they have no competing interests.

\section{Authors' contributions}

JS and YFP performed most of the experiments and analyzed data and wrote the manuscript. PJW performed some experiments and edited the manuscript. SJC reviewed and edited the manuscript. YZ and CL performed some experiments and contributed to the discussion. ZMZ and QHS edited the manuscript and contributed to the discussion. DYL designed the experiments and wrote and edited the manuscript. The authors thank Lijuan Wang (Chongqing Institute of Hypertension, China) for technical assistance. All authors read and approved the final manuscript.

\section{Acknowledgements}

This research was supported by grants from the National Basic Research Program of China (2012CB517805 and 2012CB517806) and National Natural Science Foundation of China $(81130006,81160041)$

\section{Author details}

'Center for Hypertension and Metabolic Diseases, Department of Hypertension and Endocrinology, Daping Hospital, Third Military Medical University, Chongqing Institute of Hypertension, Chongqing 400042, China. ${ }^{2}$ Teaching and Research Office for Geriatric Disease, First Affiliated Hospital of China Medical University, Shenyang 110001, China. Institute of Clinical Medicine of Zunyi Medical College,Department of Cardiology, Affiliated Hospital of Zunyi Medical College, Zunyi, Guizhou 563003, China.

Received: 18 January 2013 Accepted: 17 April 2013

Published: 22 April 2013

\section{References}

1. Zou MH, Shi C, Cohen RA: High glucose via peroxynitrite causes tyrosine nitration and inactivation of prostacyclin synthase that is associated with thromboxane/prostaglandin $\mathrm{H}(2)$ receptor-mediated apoptosis and adhesion molecule expression in cultured human aortic endothelial cells. Diabetes 2002, 51(1):198-203.

2. Jay D, Hitomi H, Griendling KK: Oxidative stress and diabetic cardiovascular complications. Free Radic Biol Med 2006, 40(2):183-192.

3. Victor VM, Rocha M, Herance R, Hernandez-Mijares A: Oxidative stress and mitochondrial dysfunction in type 2 diabetes. Current pharmaceutical design 2011, 17(36):3947-3958.

4. Kaneto H, Katakami N, Matsuhisa M, Matsuoka TA: Role of reactive oxygen species in the progression of type 2 diabetes and atherosclerosis. Mediators Inflamm 2010, 2010:1-11.

5. Roe ND, Thomas DP, Ren J: Inhibition of NADPH oxidase alleviates experimental diabetes-induced myocardial contractile dysfunction. Diabetes, obesity \& metabolism 2011, 13(5):465-473.

6. Dong YF, Liu L, Kataoka K, Nakamura T, Fukuda M, Tokutomi Y, Nako H, Ogawa H, Kim-Mitsuyama S: Aliskiren prevents cardiovascular complications and pancreatic injury in a mouse model of obesity and type 2 diabetes. Diabetologia 2010, 53(1):180-191.

7. Chu KY, Leung PS: Angiotensin II Type 1 receptor antagonism mediates uncoupling protein 2-driven oxidative stress and ameliorates pancreatic islet beta-cell function in young Type 2 diabetic mice. Antioxid Redox Signal 2007, 9(7):869-878
8. Marwick TH, Hordern MD, Miller T, Chyun DA, Bertoni AG, Blumenthal RS, Philippides $G$, Rocchini A: Exercise training for type 2 diabetes mellitus: impact on cardiovascular risk: a scientific statement from the American Heart Association. Circulation 2009, 119(25):3244-3262

9. Berardi MJ, Shih WM, Harrison SC, Chou JJ: Mitochondrial uncoupling protein 2 structure determined by NMR molecular fragment searching. Nature 2011, 476(7358):109-113.

10. Moukdar F, Robidoux J, Lyght O, Pi J, Daniel KW, Collins S: Reduced antioxidant capacity and diet-induced atherosclerosis in uncoupling protein-2-deficient mice. Journal of lipid research 2009, 50(1):59-70.

11. Tian XY, Wong WT, Xu A, Lu Y, Zhang Y, Wang L, Cheang WS, Wang Y, Yao $X$, Huang $Y$ : Uncoupling protein-2 protects endothelial function in diet-induced obese mice. Circ Res 2012, 110(9):1211-1216.

12. Ma S, Ma L, Yang D, Luo Z, Hao X, Liu D, Zhu Z: Uncoupling protein 2 ablation exacerbates high-salt intake-induced vascular dysfunction. Am J Hypertens 2010, 23(8):822-828.

13. Li L, Chen J, Ni Y, Feng X, Zhao Z, Wang P, Sun J, Yu H, Yan Z, Liu D, et al: TRPV1 activation prevents nonalcoholic fatty liver through UCP2 upregulation in mice. Pflugers Archiv : European journal of physiology 2012, 463(5):727-732.

14. Lee MS, Kim CT, Kim IH, Kim Y: Effects of capsaicin on lipid catabolism in 3T3-L1 adipocytes. Phytotherapy research : PTR 2011, 25(6):935-939.

15. Tu N, Chen H, Winnikes U, Reinert I, Marmann G, Pirke KM, Lentes KU: Molecular cloning and functional characterization of the promoter region of the human uncoupling protein-2 gene. Biochemical and biophysical research communications 1999, 265(2):326-334.

16. Ouedraogo R, Wu X, Xu SQ, Fuchsel L, Motoshima H, Mahadev K, Hough K, Scalia R, Goldstein BJ: Adiponectin suppression of high-glucose-induced reactive oxygen species in vascular endothelial cells: evidence for involvement of a cAMP signaling pathway. Diabetes 2006, 55(6):1840-1846.

17. Nilius B: TRP channels in disease. Biochimica et Biophysica Acta (BBA)-Molecular Basis of Disease 2007, 1772(8):805-812.

18. Ma L, Zhong J, Zhao Z, Luo Z, Ma S, Sun J, He H, Zhu T, Liu D, Zhu Z: Activation of TRPV1 reduces vascular lipid accumulation and attenuates atherosclerosis. Cardiovascular research 2011, 92(3):504-513.

19. Wang P, Yan Z, Zhong J, Chen J, Ni Y, Li L, Ma L, Zhao Z, Liu D, Zhu Z Transient receptor potential vanilloid 1 activation enhances gut glucagon-like peptide- 1 secretion and improves glucose homeostasis. Diabetes 2012, 61(8):2155-2165.

20. Yang D, Luo Z, Ma S, Wong WT, Ma L, Zhong J, He H, Zhao Z, Cao T, Yan Z, et al: Activation of TRPV1 by dietary capsaicin improves endotheliumdependent vasorelaxation and prevents hypertension. Cell Metab 2010, 12(2):130-141.

21. Zhang LL, Liu DY, Ma LQ, Luo ZD, Cao TB, Zhong J, Yan ZC, Wang LJ, Zhao ZG, Zhu SJ: Activation of transient receptor potential vanilloid type-1 channel prevents adipogenesis and obesity. Circulation research 2007, 100(7):1063-1070.

22. Xu X, Wang P, Zhao Z, Cao T, He H, Luo Z, Zhong J, Gao F, Zhu Z, Li L, et al: Activation of transient receptor potential vanilloid 1 by dietary capsaicin delays the onset of stroke in stroke-prone spontaneously hypertensive rats. Stroke; a journal of cerebral circulation 2011, 42(11):3245-3251.

23. Liu L, Liu J, Wong WT, Tian XY, Lau CW, Wang YX, Xu G, Pu Y, Zhu Z, Xu A, et al: Dipeptidyl peptidase 4 inhibitor sitagliptin protects endothelial function in hypertension through a glucagon-like peptide 1-dependent mechanism. Hypertension 2012, 60(3):833-841.

24. Zhao Z, Luo Z, Wang P, Sun J, Yu H, Cao T, Ni Y, Chen J, Yan Z, Liu D, et al Rosiglitazone restores endothelial dysfunction in a rat model of metabolic syndrome through PPARgamma- and PPARdelta-dependent phosphorylation of Akt and eNOS. PPAR research 2011, 2011:291656.

25. Hao X, Chen J, Luo Z, He H, Yu H, Ma L, Ma S, Zhu T, Liu D, Zhu Z: TRPV1 activation prevents high-salt diet-induced nocturnal hypertension in mice. Pflugers Archiv : European journal of physiology 2011, 461(3):345-353.

26. Inoguchi T, Sonta T, Tsubouchi H, Etoh T, Kakimoto M, Sonoda N, Sato N, Sekiguchi N, Kobayashi K, Sumimoto H, et al: Protein kinase C-dependent increase in reactive oxygen species (ROS) production in vascular tissues of diabetes: role of vascular NAD(P)H oxidase. J Am Soc Nephrol 2003, 14:S227-S232

27. Akiba Y, Kato S, Katsube K, Nakamura M, Takeuchi K, Ishii H, Hibi T: Transient receptor potential vanilloid subfamily 1 expressed in pancreatic islet beta cells modulates insulin secretion in rats. Biochemical and biophysical research communications 2004, 321(1):219-225. 
28. Van Buren JJ, Bhat S, Rotello R, Pauza ME, Premkumar LS: Sensitization and translocation of TRPV1 by insulin and IGF-I. Mol Pain 2005, 1(1):17.

29. J-a K, Montagnani M, Koh KK, Quon MJ: Reciprocal relationships between insulin resistance and endothelial dysfunction molecular and pathophysiological mechanisms. Circulation 2006, 113(15):1888-1904.

30. Muniyappa R, Montagnani M, Koh KK, Quon MJ: Cardiovascular actions of insulin. Endocrine Reviews 2007, 28(5):463-491.

31. Vicent D, llany J, Kondo T, Naruse K, Fisher SJ, Kisanuki YY, Bursell S, Yanagisawa M, King GL, Kahn CR: The role of endothelial insulin signaling in the regulation of vascular tone and insulin resistance. Journal of Clinical Investigation 2003, 111(9):1373-1380.

32. Oktavianthi S, Trimarsanto H, Febinia CA, Suastika K, Saraswati MR, Dwipayana P, Arindrarto W, Sudoyo H, Malik SG: Uncoupling protein 2 gene polymorphisms are associated with obesity. Cardiovasc Diabetol 2012, 11:41.

33. Snitker S, Fujishima Y, Shen H, Ott S, Pi-Sunyer X, Furuhata Y, Sato H, Takahashi M: Effects of novel capsinoid treatment on fatness and energy metabolism in humans: possible pharmacogenetic implications. The American journal of clinical nutrition 2009, 89(1):45-50.

34. Guarini G, Ohanyan VA, Kmetz JG, DelloStritto DJ, Thoppil RJ, Thodeti CK, Meszaros JG, Damron DS, Bratz IN: Disruption of TRPV1-mediated coupling of coronary blood flow to cardiac metabolism in diabetic mice: role of nitric oxide and BK channels. Am J Physiol Heart Circ Physiol 2012, 303(2):H216-H223.

35. Ohanyan VA, Guarini G, Thodeti CK, Talasila PK, Raman P, Haney RM, Meszaros JG, Damron DS, Bratz IN: Endothelin-mediated in vivo pressor responses following TRPV1 activation. Am J Physiol Heart Circ Physiol 2011, 301(3):H1135-H1142.

36. Song JX, Wang LH, Yao L, Xu C, Wei ZH, Zheng LR: Impaired transient receptor potential vanilloid 1 in streptozotocin-induced diabetic hearts. Int J Cardiol 2009, 134(2):290-292.

37. Lei H, Venkatakrishnan A, Yu S, Kazlauskas A: Protein kinase A-dependent translocation of Hsp90a impairs endothelial nitric-oxide synthase activity in high glucose and diabetes. Journal of Biological Chemistry 2007, 282(13):9364-9371.

38. Kassis N, Bernard C, Pusterla A, Casteilla L, Pétnicaud L, Richard D, Ricquier D, Ktorza A: Correlation between pancreatic islet uncoupling protein-2 (UCP2) mRNA concentration and insulin status in rats. Experimental Diabetes Research 2000, 1(3):185-193.

39. Rolo AP, Palmeira CM: Diabetes and mitochondrial function: role of hyperglycemia and oxidative stress. Toxicology and applied pharmacology 2006, 212(2):167-178.

40. Dhamrait SS, Stephens JW, Cooper JA, Acharya J, Mani AR, Moore K, Miller GJ, Humphries SE, Hurel SJ, Montgomery HE: Cardiovascular risk in healthy men and markers of oxidative stress in diabetic men are associated with common variation in the gene for uncoupling protein 2. European heart journal 2004, 25(6):468-475

41. Chan SH, Wu CA, Wu KL, Ho YH, Chang AY, Chan JY: Transcriptional upregulation of mitochondrial uncoupling protein 2 protects against oxidative stress-associated neurogenic hypertension. Circ Res 2009, 105(9):886-896.

42. Oniki H, Goto K, Fujii K, Kansui Y, Murakami N, Ohtsubo T, Matsumura K, Kitazono T: Effects of the Superoxide Dismutase Mimetic Tempol on Impaired Endothelium-Dependent and Endothelium-Independent Relaxations in Type II Diabetic Rats. Clin Exp Hypertens 2012, 35(2):112-119.

43. Simonsen U, Christensen FH, Buus NH: The effect of tempol on endothelium-dependent vasodilatation and blood pressure. Pharmacology \& therapeutics 2009, 122(2):109-124.

44. Inoguchi T, Li P, Umeda F, Yu HY, Kakimoto M, Imamura M, Aoki T, Etoh T, Hashimoto T, Naruse M, et al: High glucose level and free fatty acid stimulate reactive oxygen species production through protein kinase $\mathrm{C}$-dependent activation of $\mathrm{NAD}(\mathrm{P}) \mathrm{H}$ oxidase in cultured vascular cells. Diabetes 2000 49(11):1939-1945.

45. Wang Y, Nishi M, Doi A, Shono T, Furukawa Y, Shimada T, Furuta H, Sasaki H, Nanjo K: Ghrelin inhibits insulin secretion through the AMPK-UCP2 pathway in beta cells. FEBS Lett 2010, 584(8):1503-1508.

doi:10.1186/1475-2840-12-69

Cite this article as: Sun et al: TRPV1-mediated UCP2 upregulation ameliorates hyperglycemia-induced endothelial dysfunction. Cardiovascular Diabetology 2013 12:69.

\section{Submit your next manuscript to BioMed Central and take full advantage of:}

- Convenient online submission

- Thorough peer review

- No space constraints or color figure charges

- Immediate publication on acceptance

- Inclusion in PubMed, CAS, Scopus and Google Scholar

- Research which is freely available for redistribution 